\title{
Impact Assessment of Information and Communication Technologies in Agriculture: Application of The Ambitec-TICs Method
}

\author{
Daniela Maciel Pinto ${ }^{1 *}$, Priscila de Oliveira ${ }^{2}$, André Fachini Minitti ${ }^{3}$, Angelo Mansur Mendes ${ }^{1}$, Gisele Freitas \\ Vilela ${ }^{1}$, Gustavo Spadotti Amaral Castro ${ }^{1}$, Lauro Rodrigues Nogueira Júnior ${ }^{1}$, Julio Cesar Bogiani, \\ José Dilcio Rocha ${ }^{1}$, Renan Milagres Lage Novaes², Inácio de Barros ${ }^{4}$, Geraldo Stachetti Rodrigues ${ }^{2}$
}

\begin{abstract}
An extraordinary moment of agricultural modernization is currently underway due to innovations in Information and Communication Technologies (ICTs). In this process, management precepts are renewed, fostering significant gains in efficiency, productivity, and sustainable use of natural resources and the environment. The growing supply of ICTs and the extension of connectivity in rural areas, with their transforming roles in productive practices and economic relations, bring about questions regarding their impacts. These technologies include precision positioning systems and large volume databases, electronic sensors of site-specific production and environmental conditions, repositories of relational data, statistical and crop forecasting software, methodologies and processes; web-based information services, among others. The assessment of impacts focused on ICTs for agriculture needs innovative approaches, due to the peculiarities of their applications, the different scales of their socioenvironmental scopes and, at the same time, the verification of effectiveness of institutional investments on research, development, and innovation (RD\&I). Based on these premises, the objectives of this work are to present a 'module of impact indicators for Information and Communication Technologies (Ambitec-TICs)', and assess its application to six typical technology adoption cases resulting from agricultural RD\&I projects. The results detail critical analyses of the contributions of the proposed module for the registration, interpretation, and communication of impacts, with recommendations for technology transfer and accountability in institutional Social Balance documentation.
\end{abstract}

Keywords: Technological innovation; technology validation; technology transfer; Agriculture 4.0

Submitted: February $2^{\text {nd }}, 2021 /$ Approved: July $20^{\text {th }}, 2021$

\section{Introduction}

Brazil has achieved a prominent position in terms of production and international trade in agricultural products. Part of this advance stems from a successful investment in research, development, and innovation (RD\&I), carried out since the 1970s (Cabral, 2005). At the onset of this movement is the institution of the Brazilian Agricultural Research Corporation (Embrapa), attributed with the coordination of the National Agricultural Research System and with important technological contributions, which allowed the country to progress from a net food importer to its present position among the largest producers and exporters of agricultural goods (Mueller; Mueller, 2016).

To keep up with the objectives of productive intensification and technological innovation, agricultural research has been oriented towards the identification of sectoral main challenges, focusing on the generation of solutions to rural socioeconomic restraints (Embrapa, 2020). From this perspective, assessing the impacts of the adoption of technological innovations has been a strategic priority carried out since the late 1980s, and documented in the annual institutional Social Balance $^{1}$ (Avila et al., 2015).
Embrapa's Social Balance report relies on a set of methods to assess the economic, social, environmental, and institutional development impacts of research results, assets, technological solutions, and social actions (Avila et al., 2008). Essentially, these methodological approaches focus on technological applications that are immediately related to agricultural activities within rural establishments, such as machines, tools, and implements; plant varieties and animal breeds; chemical inputs; management practices and agricultural management processes, among others. More recently, however, Brazilian agriculture has experienced an extraordinary progress in the development and adoption of Information and Communication Technologies (ICTs). Only in 2019 Embrapa launched 43 technological assets classified as ICTs, represented exclusively by software, which corresponds to a share of $7 \%$ of this year's entire production of technological solutions by the corporation ${ }^{2}$. Therefore, new tools are needed for the assessment of impacts specifically entailed by ICTs as agricultural innovations.

(1) Embrapa Territorial, Campinas (SP), Brazil

(2) Embrapa Meio Ambiente, Jaguariúna (SP), Brazil

(3) Embrapa Informática Agropecuária, Campinas, Brazil

(4) Embrapa Gado de Leite, Juiz de Fora, Brazil

*Corresponding author: daniela.maciel@embrapa.br

${ }^{1}$ See an English version of Embrapa’s Social Balance report (2018) at https://bs.sede.embrapa.br/2017/socialreportembrapa2017.pdf; and the latest edition (2019, in Portuguese) at https://bs.sede.embrapa.br/2019/index.html.

${ }^{2}$ Data obtained from Embrapa's 'Sistema de Gerenciamento dos Ativos Tecnológicos' (Gestec). Available at $<$ https://sistemas.sede.embrapa.br/gestec $>$, access 10/2020 (restrict). 
Viewed as the fourth wave of the technological revolution, ICTs are powerful resources in the creation and expansion of knowledge, bringing social and cultural transformation to society and, currently, constituting tools for the emergence of a renewed rural scenario (Bernardi et al., 2015). Bolfe and Massruhá (2020), Massruhá and Leite (2017), Assad and Panceti (2009) among others, highlight the increasing adoption of ICT-based resources by farmers. In discussions about the future of agribusiness, ICTs represent a new impetus for rural development, as the Green Revolution did in the 1960's (Cadernos..., 2015).

Following this trend, the United Nations Food and Agriculture Organization (FAO) indicated the need for investments in solutions based on information and technological tools as priority for supporting developing countries' agriculture (Trendov et al., 2019). The potential for ICTs for technical assistance is also attributed to favor keeping farmers on their lands (Trendov et al., 2019), therefore preventing rural exodus, a major problem worldwide (United Nations, 2018; ; May et al., 2019). Consequently, studies on the adoption of technologies and the ensuing changes from investments in science and technology are increasingly valued by public organizations.

In the early 2000s, Horton and Mackay (2003) stressed that national and international agricultural research organizations were under growing pressure to increase their contributions to poverty alleviation, food security, sustainability in resources use, and to highlight the effectiveness of their results, i.e., their impacts. More recently, Guthrie et al (2018) stressed the value of measuring the social benefits attained from investments on public research, which are not only economic, but environmental, cultural, social, among others, as to support the planning and execution of policies to increase innovation. Hence, tools for adequately assessing impacts of technology adoption, especially in agriculture, are an increasingly challenging topic, and a necessary practice for all public institutions (Joly et al., 2016; Weißhuhn et al., 2018). This challenge is even greater when we refer to ICTs, since the methodological framework available in the literature on impact assessment seldom reach this technological typology (Gago and Rubalcaba, 2007).
Therefore, it is urgent to better understand the economic, social, environmental, and institutional contributions of the adoption of ICTs in agricultural development. Likewise, it is essential to qualify institutional performance, indicating directions for Technology Transfer (TT) actions and for setting up RD\&I agendas. The objectives of this study are to introduce a 'module of indicators for impact assessment of Information and Communication Technologies' (Ambitec-TICs, Pinto et al., 2020) and to exemplify its application through six case studies resulting from agricultural RD\&I projects. The aim is to present the method as a tool to register, interpret, and communicate the impacts of agricultural ICTs, as well as to support recommendations for technology transfer and accountability in institutional Social Balance documentation.

\section{Methodology}

AmbitecTICs - A module of indicators for impact assessment of
Information and Communication Technologies in agriculture Seeking to properly assess impacts ensuing from ICTs applied to agricultural activities, a 'module of impact indicators for Information and Communication Technologies' has been devised, based on the same premises and multicriteria approach of the method known as Ambitec-Agro (Rodrigues et al., 2003; 2010), directed towards the impact assessment of agricultural RD\&I outcomes (Monteiro and Rodrigues, 2006; Rodrigues, 2015). This proposed AmbitecTICs module considers environmental, economic, and social impact dimensions, with 65 indicators grouped into 12 criteria (Figure 1) aiming at identifying the impacts of innovations characterized as (i) information integration, (ii) data processing, and (iii) communication applied to the agricultural sector.

${ }^{3}$ United Nations, 2018. Sustainable Development Goals. Available online:. https://www.un.org/sustainabledevelopment/sustainable-development-goals.

${ }^{4}$ The Ambitec-TICs module is available on the website of Embrapa Territorial, at <www.embrapa.br/territorial/ambitec-tics $>$. 


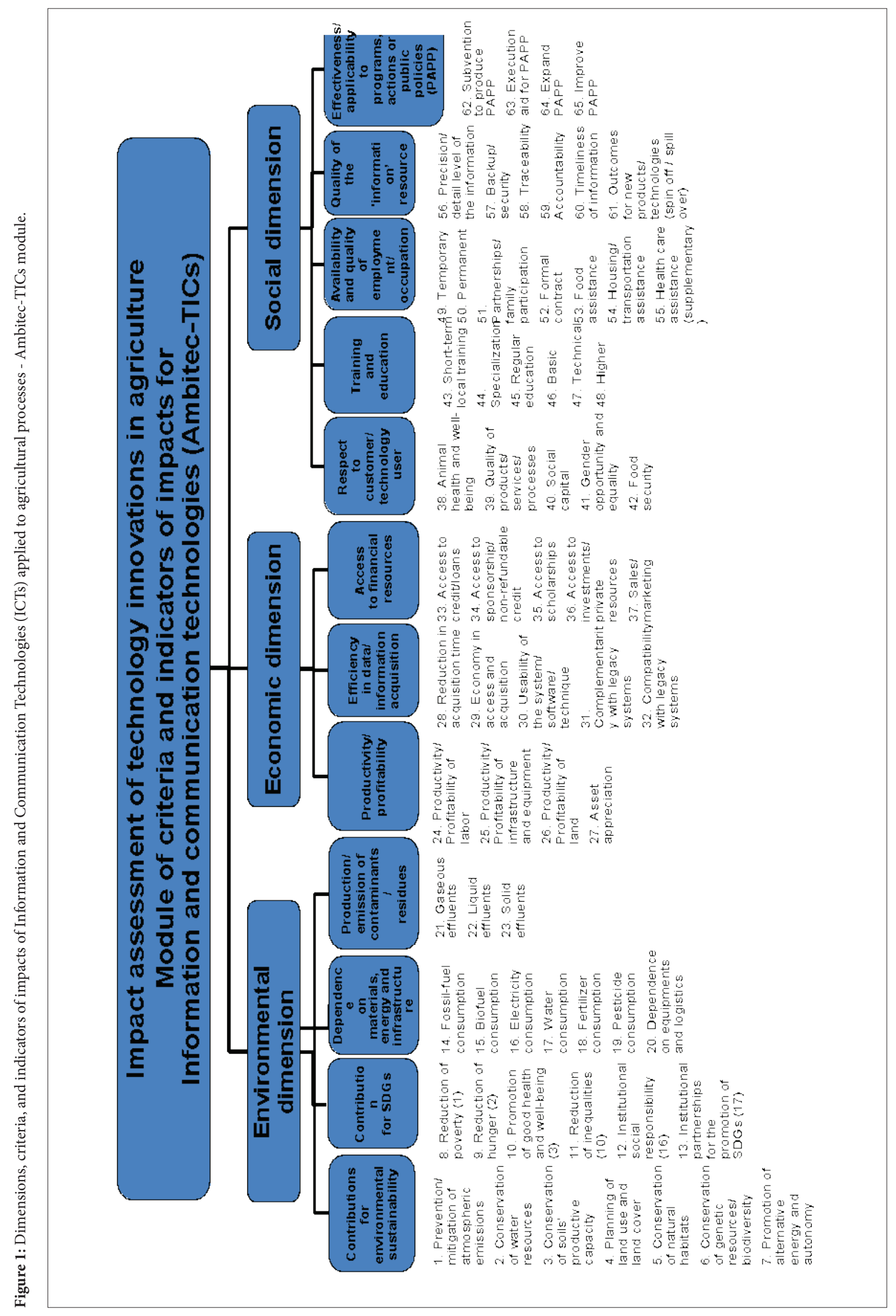


Criteria and indicators were devised to be assessed with effective users of the studied technologies, who express their knowledge about the impact of ICT adoption by means of change coefficients for each indicator (Table 1) within the scope of each criterion (Figure 1). These change coefficients represent the direction and magnitude of the impact of ICT adoption on the indicators, as verified in loco. In other words, they represent estimations of the effects resulting from an adopted technology in the managerial process, program, public policy, or productive activity.

Table 1. Observed impacts of ICT adoption on the indicator and corresponding change coefficients to be inserted in Ambitec-TICs' weighting checklists.

\begin{tabular}{l|c}
\hline $\begin{array}{l}\text { Observed impact of the ICT under the } \\
\text { specific conditions of adoption }\end{array}$ & $\begin{array}{c}\text { Indicator change } \\
\text { coefficients }\end{array}$ \\
\hline Major increase in indicator $(>25 \%)$ & +3 \\
Moderate increase in indicator $(\leq \mathbf{2 5 \%})$ & +1 \\
Indicator unaltered & 0 \\
Moderate decrease in indicator $(\leq \mathbf{2 5 \%})$ & -1 \\
Major decrease in indicator $(>25 \%)$ & -3 \\
\hline
\end{tabular}

Field evidences for these change coefficients include direct observation, administrative data, and knowledge statements from users in their specific contexts of ICT adoption. Indicator change coefficients are weighted according to their observed scales of occurrence, by factors that imply increased relative influence for larger institutional reaches, as shown in Table 2.
Table 2. Scales of impact occurrence and associated indicator weighting factors in Ambitec-TICs checklists.

\begin{tabular}{l|c}
\hline Indicator observed scales of occurrence & Weighting factors \\
\hline $\begin{array}{l}\text { Near: when the impacts influence the accomplish- } \\
\text { ment of tasks by individual users, agents, or mana- } \\
\text { gers, and their immediate teams; }\end{array}$ & 1 \\
\hline $\begin{array}{l}\text { Proximate: when the impacts influence the accom- } \\
\text { plishment of work in the scope of the department or } \\
\text { institution of the users, agents, or managers; }\end{array}$ & 2 \\
\hline $\begin{array}{l}\text { Surrounding: when the impacts influence the ac- } \\
\text { complishment of general work, including institutio- } \\
\text { nal partners, external users, and beneficiaries. }\end{array}$ & 5 \\
\hline
\end{tabular}

Indicators are finally weighted for their relative importance within the given criterion, a necessary normalization step due to the varying numbers of indicators in different criteria.

The performance coefficient for a given criterion is automatically calculated by inserting the change coefficients for all its associated indicators in their appropriate scales of occurrence (Figure 2). The results for all criteria in each dimension (i.e., environmental, economic, and social) generate the performance index for this dimension, and an impact index for the Information and Communication Technology is the weighted average of the indices in all criteria (see Figure 3 for an example).

Figure 2: Example of weighting checklist of the Ambitec-TICs impact assessment module, for the Criterion 'Effectiveness/applicability to programs, actions or public policies (PAPP)' and its associated indicators.

\begin{tabular}{|c|c|c|c|c|c|c|c|}
\hline & \begin{tabular}{|l} 
Which socio \\
variables in
\end{tabular} & $\begin{array}{l}\text { o-environ } \\
\text { 'Effectiv }\end{array}$ & $\begin{array}{l}\text { imental contrib } \\
\text { reness for public }\end{array}$ & $\begin{array}{l}\text { utions are observ } \\
\text { c policies'? }\end{array}$ & ed (or e stimatec & by the user of & he ICT for the \\
\hline $\begin{array}{r}\mathrm{E} \\
\text { ap } \\
\text { prog } \\
\mathbf{p}\end{array}$ & $\begin{array}{l}\text { ffectivenes } \\
\text { pplicability } \\
\text { rams, actio } \\
\text { ublic polici } \\
\text { (PAPP) }\end{array}$ & $\begin{array}{l}\text { ss/ } \\
\text { / to } \\
\text { ons or } \\
\text { ies }\end{array}$ & $\begin{array}{l}\text { Subvention to } \\
\text { produce PAPP }\end{array}$ & $\begin{array}{c}\text { Execution aid for } \\
\text { PAPP }\end{array}$ & Expand PAPP & Improve PAPP & $\begin{array}{c}\text { Weighting factor } \\
\text { check }\end{array}$ \\
\hline We & ighting facto & ors $\mathrm{k}$ & 0,25 & 0,25 & 0,25 & 0,25 & 1 \\
\hline II & $\begin{array}{c}\text { Not } \\
\text { applicable }\end{array}$ & $\begin{array}{c}\text { Mark w ith } \\
\mathrm{X}\end{array}$ & & & & & \\
\hline 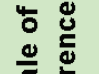 & Near & 1 & & & & & \\
\hline 焉 & Proximate & 2 & & 1 & & 1 & \\
\hline : & Surrounding & 5 & 3 & & 1 & & \\
\hline $\begin{array}{r}\text { Impact } \\
\text { coef }\end{array}$ & $\begin{array}{c}\text { coefficient = } \\
\text { fficients * weig } \\
\text { factors) }\end{array}$ & $\begin{array}{l}\text { (change } \\
\text { ighing }\end{array}$ & 3,75 & 0,5 & 1,25 & 0,5 & 6,00 \\
\hline
\end{tabular}




\section{Application of Ambitec-TICs to selected case studies}

The application of the Ambitec-TICs module was organized in three steps: 1. contextualization of the ICT adoption in the institutional environment; 2. survey with qualified ICT users of the evidences of changes ensuing from this adoption; and 3. critical analysis of the results for communication and technology transfer. Case studies were carried out between May and July 2019, involving six ICTs carefully chosen to consider different beneficiaries or adopters, types of analysis (ex-ante and ex-post), and types of technologies. To validate the results, the team in charge of technology impact assessments in the institutional Social Balance evaluated all resulting indices, with a view to issuing a qualified critique for each technology case study (Table 3).

Table 3. Selected Information and Communication Technologies experimentally assessed during the validation step of the Ambitec-TICs module.

\begin{tabular}{|c|c|c|c|c|c|c|}
\hline & Technology & $\begin{array}{l}\text { Technology } \\
\text { Category }\end{array}$ & $\begin{array}{l}\text { Technology } \\
\text { Type }\end{array}$ & Eval. type & Technology users & Focus user \\
\hline ICT 1 & $\begin{array}{l}\text { RenovaCalc }^{1}-\text { Tool for } \\
\text { tracking the environmen- } \\
\text { tal performance of biofuel } \\
\text { production }\end{array}$ & $\begin{array}{l}\text { Information inte- } \\
\text { gration and } \\
\text { Data processing }\end{array}$ & Methodology & Ex-ante & $\begin{array}{l}\text { Official and private technical as- } \\
\text { sistance companies; Private con- } \\
\text { sultants; Oleochemical and biofuel } \\
\text { industries; Groups of interest, foun- } \\
\text { dations, sectorial, and non-govern- } \\
\text { mental organizations; Government } \\
\text { agencies, institutions, companies, } \\
\text { and organizations }\end{array}$ & $\begin{array}{l}\text { Representation of the official } \\
\text { manager of the RenovaBio pu- } \\
\text { blic policy, from the Ministry of } \\
\text { Mines and Energy; estimation of } \\
\text { impacts resulting from adoption } \\
\text { of the ICT RenovaCalc (and not } \\
\text { of public policy RenovaBio pro- } \\
\text { per) }\end{array}$ \\
\hline ICT 2 & $\begin{array}{l}\text { Ainfo - Embrapa's Docu- } \\
\text { ment and Digital Collec- } \\
\text { tion Management System }\end{array}$ & $\begin{array}{l}\text { Information inte- } \\
\text { gration and } \\
\text { Communication }\end{array}$ & Software & Ex-post & $\begin{array}{l}\text { Librarians and managers of biblio- } \\
\text { graphic collections (physical and } \\
\text { electronic). }\end{array}$ & $\begin{array}{l}\text { Librarian of an agricultural re- } \\
\text { search institution }\end{array}$ \\
\hline ICT 3 & $\begin{array}{l}\text { SITE-MLog - Strategic } \\
\text { Territorial Intelligence Sys- } \\
\text { tem of Brazilian Agricultu- } \\
\text { ral Macrologistics }\end{array}$ & $\begin{array}{l}\text { Information in- } \\
\text { tegration, Data } \\
\text { processing and } \\
\text { Communication }\end{array}$ & Software & Ex-post & $\begin{array}{l}\text { Public and private managers, inves- } \\
\text { tors, assistance technicians and rural } \\
\text { extension consultants, researchers. }\end{array}$ & $\begin{array}{l}\text { Business representation of Porto } \\
\text { Açu for grains (soy and corn) ex- } \\
\text { port logistics }\end{array}$ \\
\hline ICT 4 & $\begin{array}{l}\text { GeoInfo - Embrapa's Spa- } \\
\text { tial Data Infrastructure }\end{array}$ & $\begin{array}{l}\text { Information inte- } \\
\text { gration and } \\
\text { Communication }\end{array}$ & Web Service & Ex-post & $\begin{array}{l}\text { Public and private managers, in- } \\
\text { vestors, assistance technicians and } \\
\text { rural extension agents, specialists in } \\
\text { geotechnologies. }\end{array}$ & $\begin{array}{l}\text { Researcher on geosciences } \\
\text { applied to agriculture }\end{array}$ \\
\hline ICT 5 & $\begin{array}{l}\text { GeoAtlas - Geotechnolo- } \\
\text { gies as didactic materials } \\
\text { in elementary education: } \\
\text { School Atlas of the Metro- } \\
\text { politan Region of Campi- } \\
\text { nas }\end{array}$ & $\begin{array}{l}\text { Information in- } \\
\text { tegration and } \\
\text { Communication }\end{array}$ & Methodology & Ex-post & $\begin{array}{l}\text { Elementary and high school tea- } \\
\text { chers and students. }\end{array}$ & $\begin{array}{l}\text { Geography teacher at Campinas } \\
\text { municipal education network }\end{array}$ \\
\hline ICT 6 & $\begin{array}{l}\text { CAR - Agriculture and } \\
\text { Environmental Preserva- } \\
\text { tion: analysis of the Rural } \\
\text { Environmental Registry }\end{array}$ & $\begin{array}{l}\text { Information in- } \\
\text { tegration and } \\
\text { Data processing }\end{array}$ & $\begin{array}{l}\text { Mapping } \\
\text { / planning } \\
\text { service }\end{array}$ & Ex-post & $\begin{array}{l}\text { Public and private managers, assis- } \\
\text { tance technicians and rural exten- } \\
\text { sion agents, farmers. }\end{array}$ & $\begin{array}{l}\text { ICT developer, simulating appli- } \\
\text { cation for a representative of the } \\
\text { Association of Cotton Producers } \\
\text { of Goiás State (AGOPA) }\end{array}$ \\
\hline
\end{tabular}

${ }^{1}$ In bold are the acronyms of the ICT.

A short description of each technology, their specific adoption contexts, and scope of the case studies are presented in the sections that follow.

\section{ICT 1 - RenovaCalc: a tool for tracking the environmental perfor- mance of biofuel production}

Developed by a multidisciplinary team of specialists in the areas of agroenergy production, biofuel production modeling, geoprocessing, land use change, and LCA, the computational tool 'RenovaCalc' was built to carry out the environmental energy accounting for the
Brazilian Biofuels Policy (RenovaBio), whose objective is to encourage the production and sustainable use of biofuels, so contributing to the national commitments of reduction in GHG emissions assumed at COP21 (BRASIL, 2017). Focused on the impact category 'Climate Change' in an attributional Life Cycle Analysis (LCA), the scope of the calculations is "from well to wheel" (in analogy to "from cradle to grave" in LCA studies). All flows of materials and energy in the process are considered, from the extraction of natural resources, acquisition or production and treatment of biomass, its conversion into 
biofuel, up to its combustion in engines, including all phases of transport (Folegatti-Matsuura et al., 2018). RenovaCalc is a set of spreadsheets containing: (i) a database, (ii) the specific calculation structure for each type of biofuel, (iii) the general identification data of the Production Unit, (iv) information on compliance with the program's eligibility criteria (related to avoidance of native vegetation suppression), and (v) data on the production processes, distributed in three phases: (a) agricultural (when applicable), (b) industrial, and (c) distribution.

The case study aimed at estimating the impacts of RenovaCalc according to an ex-ante context, indicating trends observed by RenovaBio managers within the Ministry of Mines and Energy, whose objective is to manage the set of biofuel plants and associated suppliers of biomass. The purpose of the study was to verify the hypothesis that the adoption of RenovaCalc generates positive technological and socioenvironmental impacts, a necessary and conducive condition for the implementation of the RenovaBio public policy.

\section{ICT 2 - Ainfo: Embrapa's Management System for Documents and} Digital Collection

Ainfo is a computer system for management of both printed and digital library collections. It includes all phases of the information processing flow, from the registration of publications, to transactions (acquisitions, loans, returns, reservations, inventory), up to full access to contents, through an advanced electronic search interface. Developed for library automation and information retrieval, it currently provides management of Embrapa's entire collection, in addition to institutional partners', reaching more than one million indexed documents. Considerable gains in scale of data processing and storage has been achieved from upgrading the system from a simple manager of institutional databases (in 1991) to an advanced information provider via the World Wide Web in its most recent version (Ainfo 6). In addition, the format of information organization made it a platform for all of Embrapa's scientific and technological information, such as Alice ('Free Access to Scientific Information'), BDPA (Agricultural Research Database) and Infoteca-e (Technological Information in Agriculture), all available to users worldwide through the internet. The case study context considered the use of Ainfo as a managing tool by a librarian in an agricultural research institution.

\section{ICT 3 - SITE-MLog: Strategic Territorial Intelligence System of} Brazilian Agricultural Macrologistics

In response to a demand from the Ministry of Agriculture, Livestock and Food Supply, the SITE-MLog tool was designed to register and spatially cross-reference national agricultural production, transport, processing, and export routes. The system identifies the country's 'harvest pathways', as to best connect agricultural production areas with transportation infrastructure (roads, highways, railways, waterways and ports, pipelines), processing plants (warehouses, slaughterhouses, feed factories), inland customs stations (called dry ports), border points, and freight terminals. Information previously dispersed in numerous databases were aptly systematized, generating over 500,000 interactive maps for the 10 main agricultural products, that account for over $90 \%$ of the national agricultural output. In addition to assisting public authorities and the private sector in decision-making regarding transportation needs, the system introduces the concept of 'logistics basins', which considers the flows of inputs and produce destinations, modeling transportation from fields to ports and viceversa. The system is constantly updated to map changes in land use and occupation, as well as predicted agricultural output, and has been already applied to 17 contracted studies for the private sector and public bodies (Embrapa Territorial, 2020a).

The SITE-MLog is an ICT whose application impacts the entire agribusiness production chain, including farmers, companies, and organizations of the sector, logistics and storage companies, in addition to public administration and policy making. This study estimated the impacts of adopting SITE-MLog by a representation of Porto do Aç $\mathrm{u}^{5}$, to operate the transportation of soy and corn in São João da Barra, Rio de Janeiro state.

\section{ICT 4 - GeoInfo: Embrapa's Spatial Data Infrastructure}

GeoInfo web service organizes and makes public all spatial data generated by Embrapa and institutional partners' research. These include maps on land use and land use change, agricultural suitability, zoning and environmental diagnostics, soil surveys, pasture productive capacity and degradation estimates, carbon emissions, watershed runoff, and many others, most available as open shapefiles for new studies. Searches on the database can be made by keywords, themes, regions, responsible institutions, among other categories. GeoInfo stores vector and matrix files formats, allowing the insertion of different file extensions (tiff, pdf maps, tables, and other geographic documents), which are recommended for registration with associated metadata, as to complement recorded information. GeoInfo is also associated with e-Science, Open Science, and Open Access as to follow national and international protocols for sharing space research data, enhancing the reuse and expansion of research by partners and society in general. The case study was developed with a researcher on geosciences applied to agriculture.

ICT 5 - GeoAtlas: Geotechnologies as didactic materials in elementary education - School Atlas of the Metropolitan Region of Campinas Despite excellent quality data being available on the geography of the Metropolitan Region of Campinas (São Paulo State), this information was not conveyed as to efficiently reach elementary school students. This educational mismatch was identified during meetings between researchers and teaching staff of local schools, who looked for Embrapa to acquiring suitable material for their pedagogical projects. In general, textbooks lack local and regional contents as they are focused on national level curricula directives. To contribute to solving this problem, efforts were made for organizing contents and themes related to local neighborhoods, the municipality, and the region surrounding the living place of the students, in order to awaken their interest in knowing their own sociocultural environments. This rapprochement between local researchers and educators contributes to bringing research results to the classrooms. In addition, it provides the basis

\footnotetext{
${ }^{5}<$ https://www.prumologistica.com.br/en/port-of-acu/>
} 
for transforming schools into spaces for producing knowledge, rather than just reproducing it, hence fostering the educational mission of building responsible citizenship.

During the GeoAtlas project, teachers from the Campinas Municipal Education Network were involved from atlas inception and design till its publication. Among the actions to encourage the use of GeoAtlas, the Municipality of Campinas created in 2013 the 'Research and Knowledge at School Program' (Pesco), a local public policy to promote research projects in schools, with themes aiming at reinforcing the students' feelings of belonging to their environment. Since its initiation, around 200 teachers and 5,000 students have gone through the program and practiced the collection, selection, organization, analysis, and dissemination of research data. At the end of each year, students share their learnings with participants from other schools in the network at events called 'Student Research Forum'. In Pesco, teachers who worked on the atlas preparation now act as tutors for other teachers that are guided by a distance learning platform. The case study context was directed towards a geography teacher at Campinas municipal education network.

ICT 6 - CAR Analysis: Agriculture and Environmental Preservation - analysis of the Rural Environmental Registry

CAR Analysis is the result of a research based upon the Rural Environmental Registry (CAR) of the Brazilian Forest Service, a numerical and cartographic database of more than five million rural establishments countrywide. This 'mapping / planning service' has been organized following demands of the Ministry of Agriculture, Livestock and Food Supply, as well as of actors of the Brazilian agriculture and forestry sectors (Embrapa Territorial, 2020b). The system identifies, qualifies, quantifies, and maps land uses, seeking to subsidize public (ministries, directories, and state secretaries) and private managers (directors and technicians of agricultural cooperatives, associations, and federations) about the mandatory guidelines of natural habitats preservation in rural establishments, at different time and space scales.

The platform presents data from microregions to states, regions, up to the entire country, with numeric and cartographic syntheses of the areas assigned to preservation and conservation of native vegetation and biodiversity, whose dimension reaches $66.3 \%$ of the national territory. Essentially, CAR Analysis monitors the role of farmers, foresters, ranchers, and extractivists to warrant environmental preservation of over a quarter of the national territory $(25.6 \%)$ within private rural spaces. The case study was applied to the ICT developer, in a project serving a representative of the Association of Cotton Producers of Goiás State (AGOPA).

\section{Results}

The application of Ambitec-TICs to the six case studies produced a broad range of scores for indicators, criteria, dimensions, and integrated impact indices (Table 4), showing the sensitivity of the indicators in discerning the impacts that ICT adoption by agriculture related sectors has on sustainability dimensions. Considerations for each specific technology are presented in the following sections.

Table 4. Selected Information and Communication Technologies evaluated with the Ambitec-TICs module and impact indices obtained for all criteria, dimensions, and integrated performance indices.

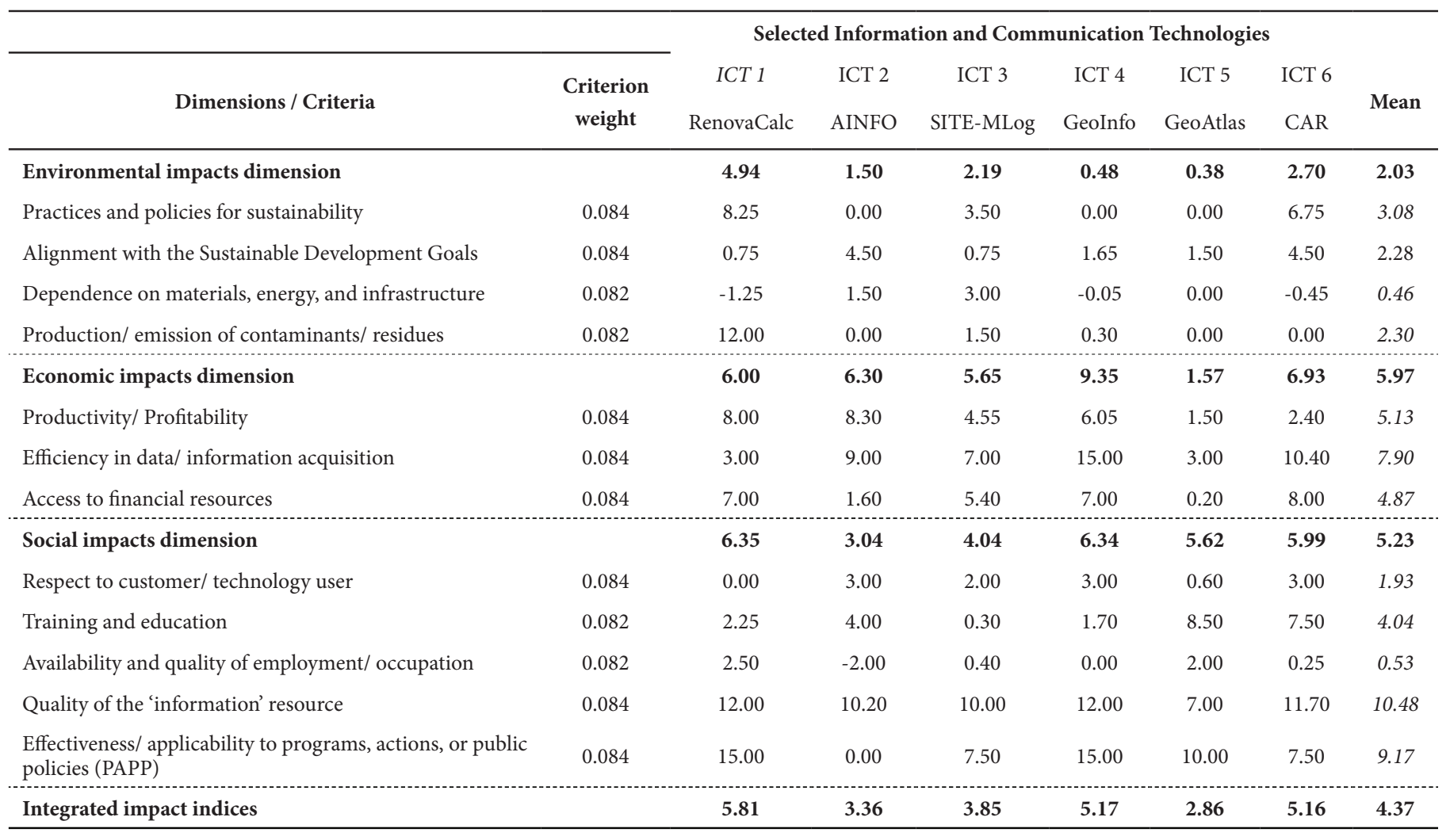




\section{ICT 1 - RenovaCalc}

RenovaCalc integrated impact index reached 5.81 (Table 4), with a positive trend for all the analyzed criteria, except for 'dependence on materials, energy and infrastructure'. Notwithstanding a trade-off between a predicted increase in pesticides, and reduction in fertilizer inputs, in relation to expected yield increases, this technology contributes to mitigating the generation of wastes and effluents, as well as to the promotion of practices and policies for sustainability, in the Environmental Impacts dimension.
In the Economic Impacts dimension, the significant contribution to productivity / profitability, especially in the use of equipment and productive infrastructure, and optimization in land use, favors access to credits and investments. Finally, moderate improvements in training, availability and quality of employment; as well as relevant contributions in data quality and information application to new programs, actions and public policies are expected in the Social Impacts dimension (Figure 3). With these characteristics RenovaCalc has been shown to be a relevant ICT for the agroenergy sector, as a support system for RenovaBio public policy decision making.

Figure 3: Graphic representation of the impact indices for the criteria, dimensions and integrated performance index for the RenovaCalc technology. Source - research data.

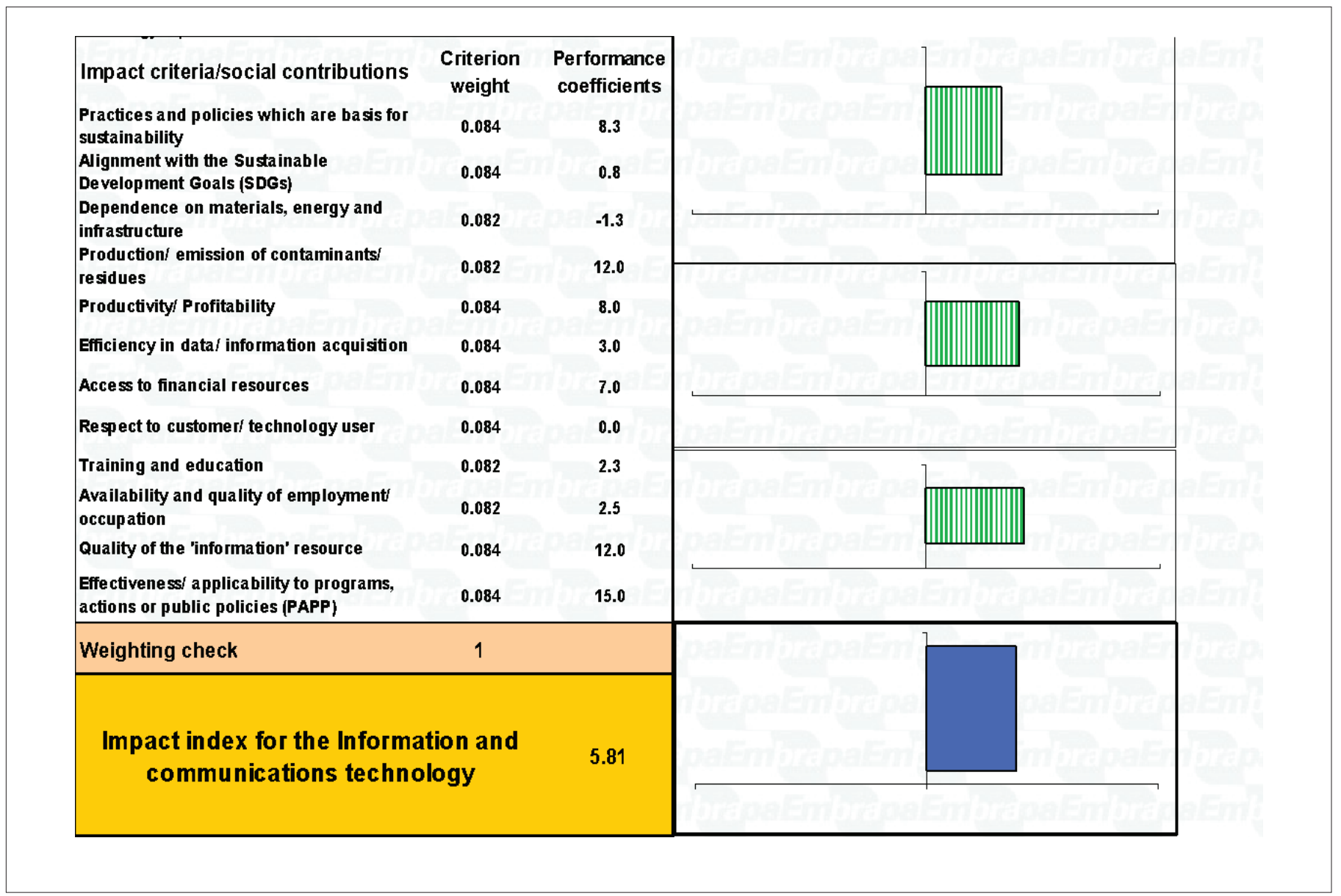

\section{TIC 2 - Ainfo}

This tool for library management and information retrieval showed a positive trend for all analyzed criteria (impact index 3.36 - Table 4), except for 'Availability and quality of work / employment', due to the curtailment of job positions resulting from library automation. In the Environmental Impacts dimension, contributions to the Sustainable Development Goals (SDGs) were highlighted, mainly regarding 'Institutional Social Responsibility' and 'Institutional Partnerships for the Promotion of SDGs. Concerning the dependence on materials and resources there is a trade-off between an increase in electricity consumption, balanced by reduced dependence on equipment and logistics, also consequence of automation and facilitated remote access.
In the Economic Impacts dimension, significant contributions to 'Productivity / profitability', and to 'Efficiency in the acquisition of data / information' demonstrate Ainfo's operational feasibility, while in the Social Impacts dimension major improvements in the 'Quality of data and information', followed by 'Respect for the consumer / technology user' and 'Training and qualification' far outweigh the only negative criterion of 'Availability and quality of work / employment' (Table 4). The effectiveness of Ainfo in managing scientific and technological information at Embrapa and partners and the beneficial impacts to society at large were attested by the positive impact indices achieved by this ICT for all environmental, economic and social dimensions of sustainability. 


\section{ICT 3 - SITE-MLog}

SITE-Mlog (impact index 3.85) tends to reduce costs by improving both inputs and produce flow efficiencies, so reaching a 4.55 productivity and profitability index (Table 4). The influence on infrastructure efficiency favors labor productivity at the local scale, while the planned organization of land uses reflects on productivity in the whole logistics basin, i.e., in the surrounding area. Therefore, appreciation in Porto do Açu and other infrastructure's asset values result from enhanced flow capacity. The criterion 'Efficiency in the acquisition of data / information' stands out (index=7.0), due to the nationwide integration of data on organized production and infrastructure connectivity. Also, infrastructure efficiency reduces wastes along the transport chain, favoring the performance in the 'Respect for the consumer and user of the technology' (index=2.0). The main feature of SITE-MLog is to present a precise and detailed data on the logistics of agricultural production, combined with quality information rendered by renowned companies and government agencies that are constantly updated. Hence, the 'Quality of the information resource' criterion showed the highest performance index (10.0). Finally, as SITE-MLog is focused on supporting decision-making towards priority policy objectives, the performance for the 'Effectiveness and applicability for programs, actions or public policies' criterion reached an index as high as 7.5.

\section{ICT 4 - GeoInfo}

GeoInfo (impact index 5.17 - Table 4) showed positive trends for most studied criteria, except for 'Basic practices and policies for sustainability', 'Supply and quality of work / employment' (both unaffected) and 'Dependence on materials, energy, and infrastructure' (slightly negative, index $=-0.05$ ). Contribution to the SDGs, i.e., institutional social responsibility and reduced consumption of fossil fuels, were highlighted in the Environmental Impacts dimension. In the Economic Impacts dimension, GeoInfo contributed greatly for improving the Efficiency in acquisition of data / information, with emphasis on indicators of economy and practicality, as well as in those related to technological interfaces. Productivity/ profitability also stood out, through improvements in labor, infrastructure, and equipment efficiencies. In the Social Impacts dimension, moderate improvements were detected in 'supply and quality of employment' and 'training and education', while this ICT yielded most relevant contributions to the quality of data and information, and to their application in new programs, actions, and public policies (Table 4). With these indications, GeoInfo proved to be a relevant technological solution for specialists, producers, and users of spatial data, contributing to the process of geoinformation dissemination and the premises of the e-Science paradigm.

\section{ICT 5 - GeoAtlas}

In the adoption context of the case study, the pedagogical use of GeoAtlas did not directly promote environmental changes, aside from favoring alignment with the Sustainable Development Goals school's institutional responsibility, and partnerships to promote the SDGs. All remaining criteria, in both Economic and Social impact dimensions, showed positive trends, and the integrated impact index reached 2.86 (Table 4). Economic impacts were modest, resulting from slight gains related to productivity in the use of school's equipment and infrastructure, and important improvements in (territorial) data and information acquisition and communication. In the social impacts dimension, moderate improvements in training, as well as supply and quality of employment were associated with relevant contributions to the quality of data and information, and their application in new programs, actions, and public policies. These impacts indicate that GeoAtlas is a relevant pedagogical tool, with positive implications for social improvements and supporting local public policy to promote the SDGs.

\section{ICT 6 - CAR Analysis}

Overall performance index of CAR Analysis was 5.16 (Table 4). Except for a slight negative index on Dependence on materials, energy, and infrastructure criterion $(-0.45)$, positive trends were observed for all analyzed criteria. In the Environmental Impacts dimension, promotion of basic practices and policies for sustainability stood out, while 'efficiency in the acquisition of data and information' and 'access to financial resources' were highlighted in the Economic Impacts dimension. By fostering improvements in 'quality of the information resource', 'training and qualification', and 'effectiveness and applicability for Programs, Actions, and Public Policies (PAPP)', this ICT showed its value to promote positive Social Impacts. With these characteristics, CAR Analysis showed to be a relevant technological solution for the agricultural sector, and an unavoidable tool to support the fulfillment of international agreements for biodiversity conservation, and conformity with mandatory rules of the national Forest Code.

\section{Discussion}

The absence of a methodology to assess the impacts of information and communication technologies prevented the adequate measurement of the values obtained by the productive sector from the adoption of these technologies. With the formulation of specific criteria and indicators, it becomes possible to identify the impact of innovations associated with the production and use of data and information oriented to agriculture, which support users (extension workers, researchers, producers, public and private managers, etc.) in agricultural practices, in research, development and technology transfer processes.

The specific case of the ex-ante evaluation carried out on the RenovaCalc showed that the Ambitec-TICs module proved to be applicable to predict potential gains from technology adoption. All the remaining technologies assessed showed improvements on the criteria of Efficiency in the acquisition of data/information and Quality of the 'information' resource, with indices varying from 7.0 to the 15.0 maximum.

The growing supply of ICTs for the agricultural sector requires the assessment of impacts as a means of appraising their contributions and directing their update, maintenance, and evolution in the institutional and market contexts. With the proposed Ambitec-TICs approach, an instrument for ICTs focused on agricultural development is made available. It is appropriate to admit that Ambitec-TICs requires continuous assessment of its structure, for possible adaptations, 
and should evolve at a pace compatible with the institutional learning of the teams involved with the impact assessment process (Rodrigues et al., 2010). The experimental application of the Ambitec-TICs module to different ICT typologies was found to be satisfactory among the groups of evaluators. The interpretation of impacts related to the adoption of such diverse technologies fosters the evolution of agricultural practices, technology transfer actions, as well as influences legal provisions to stimulate and develop national agriculture.

\section{Conclusions}

Ambitec-TICs module is introduced here as a tool to fill the gap in support systems to assess the impacts that the adoption of agribusiness-related information and communication technologies have on different indicators of sustainable development, notably on environmental, economic, and social dimensions and criteria.

The application of the tool to six case studies that encompasses a broad range of adoption contexts, types of evaluation (ex-ante and ex-post), types of technologies (from web applications to mapping), and technology application objectives (from territorial intelligence for macrologistics to didactic material for elementary schools), attest to the ability of Ambitec-TICs module to highlight the strengths and weaknesses of the evaluated technologies, as well as its flexibility to be applied on a wide scope of ICTs, therefore being a promising tool for institutional evaluations of adoption impacts, including for ex-ante assessments.

The general observations on the case studies showed that the adoption of agriculture related ICTs have important impacts on the quality of information resources, as expected as such technologies are conceived with the aim of making a better and more efficient use of information.

\section{References}

Assad L \& Pancetti A (2009). A silenciosa revolução das TICs na agricultura. Comciência Rev Elet Jornal Cie 110, Available at <http://comciencia.scielo.br/pdf/cci/n110/a05n110.pdf>, access 12/2020.

Avila AFD, Rodrigues GS \& Vedovoto GL (2008). Avaliação dos impactos de tecnologias geradas pela Embrapa: metodologia de referência. Embrapa Informação Tecnológica. Available at <https://ainfo.cnptia.embrapa.br/ digital/bitstream/item/149960/1/2008OL-01.pdf>, access 12/2020.

Avila AFD, Rodrigues GS, Vedovoto GL, Penteado Filho RC \& Fonseca Jr WC (2015). Embrapa experience on the impact assessment of agricultural R\&D: 15 years using a multidimensional approach. ImPAR Conference: Impacts of agricultural research - towards an approach of societal values.

Bernardi ACC, Fragalle CVP, Fragalle EP, Silva JC \& Ynamasu RY (2015). Estratégias de comunicação em agricultura de precisão. Persp Cie Inf 20, 189-200.

Bolfe EL \& Massruhá SMFS (2020). A transformação digital e a sustentabilidade agrícola. Agroanal 40, 32-34.
BRASIL. Lei no 13.576, de 26 de dezembro de 2017. Dispõe sobre a Política Nacional de Biocombustíveis (RenovaBio) e dá outras providências.

Cabral JI (2005). Sol da manhã: memória da Embrapa. UNESCO, Memória Embrapa.

Cadernos Temáticos do Observatório (2015). TIC no agronegócio. Available at <file:///C:/Users/vidat/Downloads/TICnoagronegcio2016PORTUGUS_VERSOFINAL1.pdf >, access 12/2020.

Embrapa (2020). VII Plano Diretor da Embrapa 2020 - 2030. Available at <https://ainfo.cnptia.embrapa.br/digital/bitstream/item/217274/1/ VII-PDE-2020.pdf>, access 12/2020.

Embrapa Territorial (2020a). Sistema de Inteligência Territorial Estratégica da Macrologística Agropecuária brasileira (SITE-MLog). Available at <www.embrapa.br/macrologistica $>$, accessed 11/2020.

Embrapa Territorial (2020b). Agricultura e preservação ambiental: uma análise do cadastro ambiental rural. Available at $<$ www.embrapa. br/car>, accessed 11/2020.

Folegatti-Matsuura MIS, Seabra JEA, Chagas MF, Scachetti MT, Morandi MAB, Moreira MMR, Novaes RML, Ramos NP, Cavalett O \& Bonomi A (2018). RenovaCalc: a calculadora do Programa RenovaBio. Congresso Brasileiro Sobre Gestão do Ciclo de Vida 6, 162-167.

Gago D \& Rubalcaba L (2207). Innovation and ICT in service firms: towards a multidimensional approach for impact assessment. J Evol Econ 17, 25-44.

Guthrie S, d'Angelo C, Ioppolo B, Shenderovich Y. McInroy GR. Evidence Synthesis on Measuring the Distribution of Benefits of Research and Innovation. Cambridge: RAND Europe; 2018.

Horton D \& Mackay R (2003). Using evaluation to enhance institutional learning and change: recent experiences with agricultural research and development. Agr Sys 78, 127-142.

Joly PB, Colinet L, Gaunand A, Lemarié S \& Matt M (2016). Agricultural research impact assessment: issues, methods and challenges. OECD Food, Agriculture and Fisheries Papers 98. Available at $<\mathrm{http} / /$ dx.doi.org/10.1787/5339e165-en> access on 12/2020.

Massruhá SMFS \& Leite MAA (2017). Agro 4.0 - rumo à agricultura digital. JC Escola Ciência, Tecnologia e Sociedade 2, 28-35.

May D, Arancibia S, Behrendt K \& Adams J (2019). Preventing young farmers from leaving the farm: investigating the effectiveness of the young farmer payment using a behavioural approach. Land Use Pol 82, 317-327.

Monteiro RC \& Rodrigues GS (2006). A system of integrated indicators for socio-environmental assessment and eco-certification in agriculture - Ambitec-Agro. J Technol Manag Innov 1, 47-59. 
Mueller B \& Mueller C (2016). The political economy of the Brazilian model of agricultural development: Institutions versus sectoral policy. Quart Rev Econ Fin 62, 12-20.

Pinto DM, Oliveira P, Minitti AF, Mendes AM, Vilela GF, Castro GSA, Rocha JD, Bogiani JC, Nogueira Jr LR, Costa CC, Novaes RML \& Rodrigues GS (2020). Ambitec-TICs: avaliação de impactos de tecnologias de informação e comunicação aplicadas à agropecuária. Embrapa Territorial Documentos, 131.

Rodrigues GS, Campanhola C \& Kitamura PC (2003). An Environmental impact assessment system for agricultural R\&D. Envir Imp Assess Rev 23, 219-244.
Rodrigues GS, Buschinelli CCA \& Avila AFD (2010). An environmental impact assessment system for agricultural research and development II: institutional learning experience at Embrapa. J Technol Manag Innov 5, 38-56.

Rodrigues GS (2015). Avaliação de impactos socioambientais de tecnologias na Embrapa. Embrapa Meio Ambiente. Documentos 99.

Trendov NM, Varas S \& Zeng M (2019). Tecnologías digitales en la agricultura y las zonas rurales. Documento de Orientación FAO. Available at <www.fao.org/3/ca4887es/ca4887es.pdf>, access 12/2020.

Weißhuhn P, Helming K \& Ferretti J (2018). Research impact assessment in agriculture - A review of approaches and impact areas. Res Eval 27, 36-42. 